\title{
Makam Sayyid Husein bin Abu Bakar al-Aydarus: Jaringan Spiritual Usmani di Indonesia akhir abad ke-191
}

\section{FRIAL RAMADHAN SUPRATMAN}

Istanbul University, Turkey

Email: frialramadhan1@gmail.com

\section{ABSTRACT}

This article investigates Indonesian history with transnational approach especially in tracing social community of Indonesia in the context of globalization during nineteenth century. In this article, author focuses on holy tomb of ulama or saint (wali), Sayyid Husein bin Abu Bakar al-Aydarus, who died in the late eighteenth century and buried in Batavia. Although he died more than a century a go, his influence through tomb still can be sensed until now. In the nineteenth century, the tomb of Sayyid Husein bin Abu Bakar al-Aydarus became a symbolic mediator of Arab Hadrami communities in Batavia to build contact with the only Independence Muslim states, Ottoman state, after the decline of Mughal state in 1857. In the late nineteenth century, Hadrami communities requested donation from Ottoman sultan or Caliph to repair the tomb of Sayyid Husein bin Abu Bakar al-Aydarus. Upon this request, author concludes that in the middle of modernization and globalization, Ottoman government in Istanbul at that juncture was still concerned to preserve its spiritual network wiwth Indonesian Archipelago based on the Tradition of Islam (al-din).

Keywords: Al-Aydarus, Tomb, Spiritual Networking, Ottoman state, Batavia

\section{ABSTRAK}

Artikel ini mencoba meneliti sejarah Indonesia dengan pendekatan transnasional, khususnya dalam melacak peran komunitas sosial yang ada di Indonesia dalam konteks globalisasi yang terjadi pada abad ke-19. Di sini penulis akan memfokuskan pada makam keramat seorang ulama di Batavia yang bernama Sayyid Husein bin Abu Bakar al-Aydarus. Dia adalah seorang ulama atau wali yang meninggal pada akhir abad ke-18 dan dimakamkan di Batavia. Meskipun sudah wafat, namun pengaruh dari makamnya masih terasa hingga kini. Pada abad ke-19, makam Sayyid Husein bin Abu Bakar al-Aydarus menjadi mediator simbolik bagi komunitas Arab Hadrami yang ada di Batavia untuk melakukan 
kontak dengan negara Islam yang masih independen, Usmani (Ottoman State/ Osmanlý Devleti) setelah kejatuhan Kesultanan Mughal tahun 1857. Pada akhir abad ke-19, komunitas Hadhrami meminta sultan Usmani, yang juga bergelar Khalifah, agar meminta donasi untuk memperbaiki makam Sayyid Al-Aydarus. Permintaan bantuan ini menyimpulkan bahwa di tengah proses modernisasi dan globalisasi akhir abad ke-19 yang membawa nilai-nilai materialistik dan sekuler, pemerintah Usmani di Istanbul tetap menjaga jaringan spiritual di Samudera Hindia yang didasarkan pada tradisi Islam (al-din).

Kata Kunci: Al-Aydarus, Makam, Jaringan Spritual, Usmani, Batavia

\section{PENDAHULUAN}

Pada akhir abad ke-19, tepatnya pada tahun 1898, terdapat sebuah laporan di dalam arsip Usmani di Istanbul yang menyatakan adanya permintaan bantuan donasi dari orang-orang Arab di Batavia. Donasi tersebut diperuntukkan untuk membangun sekolah, masjid dan memperbaiki makam seorang ulama bernama Sayyid Husein bin Abu Bakar al-Aydarus. ${ }^{2}$ Dokumen yang tersimpan di kota yang sangat jauh dari makam Al-Aydarus di Batavia, tidak hanya menyimpulkan adanya hubungan antara Usmani dengan Muslim di Indonesia pada akhir abad ke-19 saja, namun lebih dari itu, dokumen ini memberikan makna yang sangat luas bagi sejarah transnasional di Samudera Hindia dan hubungan Inter-Asia di akhir abad ke-19 yang selama ini banyak didominasi oleh narasi kolonialisme.

Artikel ini ingin menjawab pertanyaan besar mengenai jaringan negaranegara Asia yang ada di Samudera Hindia pada abad ke-19. Sejauh ini narasi mengenai sejarah transnasional dan global masih didominasi oleh pandangan yang cenderung menekankan kekuatan struktural sebagai pengikat kesatuan di dalam hubungan antar Asia, khususnya di Samudera Hindia. Ini dipengaruhi oleh sejarawan Eropa seperti Braudel (1992) yang mengkaji Laut Mediterania dengan menekankan pada pentingnya duniaekonomi yang bercorak kapitalistik sebagai faktor pengikat negara-negara Mediterania. ${ }^{3}$ Dalam bukunya, Braudel menekankan adanya suatu dunia ekonomi tersendiri yang ditandai oleh beragam karakteristik seperti adanya pusat kota yang bercorak kapitalis. Dalam hal ini Braudel menganalisa negara-negara Mediterania dengan ukuran ekonomi kapitalis yang dapat menembus batas-batas peradaban. Dengan adanya dunia-ekonomi yang diberangi oleh ekspansi imperialisme negara-negara Eropa seperti Portugis, Spanyol, Inggris, Belanda, ke Amerika, Asia dan Afrika, maka selanjutnya menciptakan sistem-dunia modern yang berpusat di kota-kota dagang Eropa, sehingga terjadi hubungan antara pusat dan periferi. 
Kajian yang serupa pun dilakukan oleh Wallerstein (2011). Dalam bukunya Wallerstein menyatakan bahwa hanya ada satu sistem-dunia modern. Bahkan ia merujuk bahwa jikalau ada yang lain, maka mungkin itu berada di planet lain yang dapat dibandingkan dengan sistem-dunia modern yang tunggal. ${ }^{4}$ Wallerstein menunjukkan bahwa terdapat hubungan pusat (kota-kota Eropa) dengan periferi (kota-kota Asia, Afrika dan Amerika) dalam membentuk sistem dunia modern yang bercorak kapitalistik. Namun dalam hal ini, Wallerstein terlalu menekankan pentingnya wilayah pusat (Eropa) dalam menjalankan perannya atas wilayah periferi. Tentu saja di sini, Braudel dan Wallerstein mengabaikan kekuatan suprastruktur seperti agama yang menjadi spirit bagi masyarakat Asia dalam melakukan interaksi.

Bahkan dalam karya mengenai Samudera Hindia, Chaudhuri (1992) pun lebih mengutamakan kekuatan struktur di mana fisik (lingkungan geografis) dan masyarakat memainkan peran penting dalam interaksi di Samudera Hindia. Di dalam buku ini Chaudhuri menekankan pada Teori Logika Sejarah bahwa transformasi mental atas spasial, waktu dan struktur beritndak sesuai simbol fisik melalui sebuah aksi. Misalnya dalam spasial Samudera Hindia, kondisi laut yang berbahaya menentukan tindakan para pedagang yang melintasinya. Jarak menentukan teknik pembuatan kapal dan metode navigasi, serta karakteristik musim di laut menentukan waktu pelayaran, dan waktu karavan dalam membawa barang ke pelabuhan. ${ }^{5}$ Dari sini Chaudhuri menekankan kekuatan fisik. Meskipun Chaudhuri membahas mengenai spiritual dan agama, namun tetap faktor fisik dan kegiatan ekonomi menjadi penyatu dalam interaksi di Samudera Hindia.

Interaksi yang menekankan kekuatan fisik ini sudah ditinjau ulang oleh beberapa sejarawan seperti Bose (2006),Tagliacozzo (2013) dan Ho (2006). ${ }^{6}$ Dari karya-karya tersebut kita mengetahui bahwa interaksi antar negara-negara Asia tidaklah sederhana seperti yang dibayangkan oleh Chaudhuri, Braudel dan Wallerstein. Hubungan pusat dan periferi yang bercorak kapitalistik tidak selalu mendominasi kesatuan di Samudera Hindia. Pada akhir abad ke-19, justru ketika kapitalisme Eropa sedang menguat, maka Samudera Hindia sedang mengali proses spiritualisasi dengan adanya peran yang dimainkan oleh Khilafah Usmani yang berkedudukan di Istanbul. Semangat Pan-Islamisme atau Persatuan Islam (Ýttihad-ý Ýslam) menjadi pengikat negara-negara Muslim yang ada di Samudera Hindia. Beberapa studi yang dilakukan oleh Eraslan (1992), 
Çetinsaya (1988) dan Özcan (1997). ${ }^{7}$ Mereka menekankan peran yang dimainkan oleh Sultan Abdulhamid II sebagai khilafah dalam menggelorakan persatuan Islam untuk mendukung Usmani di tengah konflik Eropa yang sedang berkecamuk pada abad ke-19. Namun artikel ini tidak akan berbicara lebih jauh mengenai konsep Pan-Islamisme.

Artikel ini bertujuan untuk menjelaskan kesatuan yang mengikat negaranegara Muslim di Samudera Hindia. Dalam hal ini penulis menjelaskan bahwa ikatan spiritual dalam bentuk donasi yang dimaksudkan untuk memperbaiki makam Sayyid al-Aydarus memainkan peran penting dalam hubungan antar negara Asia di akhir abad ke-19. Di sini kita menekankan pentingnya jaringan spiritual dalam mengikat kesatuan di Samudera Hindia, khususnya antara Istanbul dan Batavia.

Penulis mencoba menyuarakan pandangan dari S. H. Nasr yang mengedepankan spiritualitas dalam menganalisa masyarakat non-Barat khususnya Asia. Dalam bukunya Nasr menyatakan bahwa Barat telah melakukan desakralisasi pengetahuan sehingga kita tidak dapat melihat dunia dengan utuh. Dalam hal ini telah terjadi pereduksian intelektual hanya dalam tahap alasan (reason) sehingga dimensi metafisik diabaikan. ${ }^{8}$ Untuk itu penulis menilai perlu adanya analisa yang didasarkan suprastruktur seperti spiritualitas, bukan hanya struktural dalam melihat interaksi Usmani dan Indonesia dalam perbaikan makam al-Aydarus sebagai unit yang menyatukan antar negara-negara mayoritas Muslim di Samudera Hindia. Dalam hal ini penulis ingin menunjukkan bahwa jaringan spiritualitas yang dimaksud dalam tulisan ini adalah sebuah hubungan yang saling mengikat antar negara dengan mengandalkan kekuatan spiritual. Di sini kita takkan dapat memahami mengapa Usmani menyumbangkan sejumlah uang untuk memperbaiki makam Sayyid al-Aydarus jika kita mengabaikan aspek spiritualitas. Hal ini juga dipengaruhi oleh jaringan sufi yang saling bertautan antara Istanbul dan Samudera Hindia sehingga posisi makam Sayyid alAydarus dapat dipahami. Dengan demikian penulis berargumen bahwa spiritualitas merupakan faktor pengikat yang menyatukan negara-negara mayoritas Muslim di Samudera Hindia sehingga makam al-Aydarus merupakan simbol bagi keberadaan jaringan spiritualitas yang menyatukan Istanbul dan Batavia.

\section{DARI ISTANBUL KE BATAVIA: JARINGAN TAREKAT ALAWIYAH}

Untuk menganalisa makam al-Aydarus sebagai simbol dari jaringan 
spiritualitas antara Istanbul dan Batavia, maka ada baiknya kita mengetahui komunitas Hadrami dan jaringan tarekat Alawiyah di Samudera Hindia. Orang-orang Arab Hadrami di Indonesia memainkan peran yang sangat penting dalam interaksi ekonomi dan kebudayaan yang menyatukan Indonesia dengan negara-negara di Samudera Hindia. Laporan van den Berg mengenai orang-orang Arab Hadrami di Indonesia merupakan kajian yang sangat penting. Bahkan dapat dikatakan ini adalah sumber yang merepresentasikan pandangan pemerintah kolonial Belanda dalam menjelaskan mengenai posisi Arab Hadrami di Indonesia. Namun dalam pandangan penulis, pandangan Berg terhadap Arab Hadrami sangatlah sederhana sehingga dia menilai Arab Hadrami sebagai masyarakat yang oportunis sehingga Berg tidak mampu melihat jaringan masyarakat Arab Hadrami dengan baik.

Pandangan Berg yang kurang baik terhadap Hadrami juga diperlihatkan ketika ia menganalisa hubungan antara Usmani dan Hadrami. Dalam hal ini, seperti yang disebutkan di atas, ia melihat Hadrami dengan sederhana, sebatas kepentingan ekonomi saja.

Jikalau Porte (Pusat Birokrasi Usmani) memobilisasi suku-suku Hadramaut, saya hampir yakin bahwa beberapa akan memanggul senjata, bukan karena solidaritas agama, melainkan karena berharap memperoleh rampasan yang berharga. Dan Porte segera bosan mengacapi pembatu yang tidak disiplin, yang sama sekali tidak memikirkan kewibbawaannya sebagai khalifah penerus Nabi, dan yang mungkin sekali tidak mampu membedakan antara umat Kristen dan para petugas pegawai Turki yang memperoleh pendidikan di Paris atau London yang otaknya penuh dengan gagasan modern. ${ }^{9}$

Untuk itu Berg kurang jeli dalam melihat pengaruh gerakan tarekat dalam skala yang lebih luas. Untuk hal ini sebenarnya masyarakat Hadrami di Indonesia dan Semenanjung Melayu memiliki jaringan spiritualitas yang kuat di Samudera Hindia. Dalam hal ini, selain perdagangan, tarekat adalah faktor yang sangat penting untuk memperlihatkan jaringan Hadrami di wilayah Samudera Hindia.

Diaspora orang-orang Hadramaut dapat dilihat melalui genealogi atau silsilah generasi yang hidup di luar Hadramaut. Seluruh silsilah tersebut diketahui melalui teks, puisi, doa, hingga batu nisan. Dari silsilah tersebut, orang-orang Hadrami yang berdiaspora di luar Hadramaut menjadi terikat. Kebanyakan silsilah keturunan dari orang Hadrami tersebut menyatu di 
kuburan-kuburan di Tarim, yang juga dapat dilacak hingga nabi Muhammad. Sehingga dalam hal ini, batu nisan menunjukkan adanya diaspora yang pengaruhnya lebih besar daripada 'globalisasi'. Dalam diaspora yang ditujukan oleh batu nisan memperlihatkan adanya masyarakat yang absen daripada masyarakat yang hadir. Untuk diaspora, masyarakat yang absen dapat menjadi sangat produktif. Ini mengabsahkan masyarakat untuk mengasah kemampuan baru, menciptakan puisi dan tulisan, mengirim uang, ide, istri, anak dan rumah baru. Kematian membuat mereka harus menulis obituari dan silsilah seperti yang ada di batu nisan.${ }^{10}$ Untuk itu dalam hal ini kita melihat adanya jaringan yang disatukan oleh adanya masyarakat yang absen di dalam masyarakat Hadrami. Justru dengan absen, jaringan diaspora Hadrami semakin kuat karena mengharuskan mereka untuk mengikat diri mereka dengan leluhur dengan berbagai cara, seperti melalui teks-teks mengenai silsilah hingga doa-doa yang dipanjatkan kepada leluhur.

Dalam konteks ini, maka kekuatan dari tarekat Alawi di Samudera Hindia tidaklah diragukan lagi. Dalam diaspora Hadrami, para sayyid memainkan peran penting di wilayah-wilayah diaspora seperti di Indonesia. Kebanyakan mereka berasal dari keturunan yang sama di Hadramaut yaitu dari Ahmad bin Isa. Dia meninggalkan kampung halamannya di Basra, Irak, dan bepergian ke Hijaz dan Yaman sebelum akhirnya memasuki Hadramaut pada tahun 932. ${ }^{11}$ Setelah itu para keturunannya terus menyebar di wilayah Hadramaut. Melakukan perkawinan dengan penduduk lokal merupakan salah satu cara untuk memperluas posisi Sayyid di dalam masyarakat Hadrami.

Setelah Hadramaut dijadikan tempat menetap, maka para Sayyid pun melakukan migrasi ke luar wilayah Hadramaut seperti ke Afrika Timur, Asia Selatan dan Asia Tenggara. Dalam diasporanya, mereka membantu penyebaran tarekat Alawiyah ke berbagai wilayah. Di Indonesia mereka mendirikan organisasi bernama Rabita Alawiyah pada tahun 1927. Keluarga Sayyid yang mendominasi di Indonesia pada tahun 1933 adalah Al-Attas, Al-Aydarus, Al-Haddad, Al-Hibshi, A-Saqqaf dan Al-Shihab. Sementara keluarga Syaikh Abu Bakar bin Sallim memiliki jumlah yang cukup banyak di Afrika Timur. Migrasi ke Pantai Swahili meningkat pada abad ke-19 seiring dengan kebijakan Sultan Oman yang memberikan banyak perlindungan untuk kegiatan dagang dan belajar agama. Sehingga kota-kota pantai di Swahili seperti Zanzibar, Lamu dan Pulau Komoro 
menjadi pusat interaksi antara Hadramaut dan Afrika Selatan. ${ }^{12}$

Pada masa pemerintahan Abdulhamid II (1876-1909), Istanbul menjadi tempat destinasi banyak para Sayyid, khususnya dari tarekat Alawi. Mereka datang ke Istanbul untuk mencari patron yang dapat mendukung kegiatan mereka. Saat itu memang Abdulhamid II memang sedang menggelorakan persatuan Islam (ittihad-i Islam) karena dia merupakan khalifah Usmani yang berkewajiban dalam melindungi Muslim dari tekanan imperialisme Barat. Selain itu, politik persatuan Islam yang dilakukan oleh Abdulhamid II juga merupakan implikasi dari posisi Usmani di tengah konflik Eropa. Sultan Abdulhamid II menginginkan agar Muslim di wilayah Usmani bersatu dalam mengehadapi perang melawan Rusia pada tahun 18771878. ${ }^{13}$ Atas dasar ini, maka para Sayyid banyak yang mencari perlindungan di bawah kekuasaan Abdulhamid II.

Salah satu penganut tarekat Alawiyah yang menjadi penasihat Abdulhamid II adalah Sayyid Fadl. Dia merupakan salah satu penasihat Abdulhamid II disamping Muhammad Zafir bin Muhammad al-Tarablusi (1829), Ahmad As'ad dan Abu'l-Huda al-Sayyadi (meninggal tahun 1909). ${ }^{14}$ Nama asli dari Sayyid Fadl adalah Fadl bin al-Ghaws bin Muhammad bin Sahll Mawlla al-Duwaylla al Alawi al-Husayni. Dia memainkan peran yang penting di dalam konflik di Samudera Hindia. Ayahnya adalah seorang pemimpin gerakan Pan-Islamisme yang terkenal di Kalkuta. Setelah kematian ayahnya, dia melanjutkan berjuang menjadi tokoh Pan-Islam. Pada tahun 1852, Inggris kemudian mengusir Sayyid Fadl. la pergi ke Mekkah kemudian datang ke Istanbul di mana ia mendapatkan penghargaan di sana. ${ }^{15}$ Pada tahun 1875, Sayyid Fadl menerima undangan dari ketua suku Dhofar untuk memimpin mereka melawan Inggris, dan dia menerima tawaran ini sehingga secara sepihak Seyyid Fadl mendeklarasikan bahwa Dhofar adalah bagian dari wilayah Usmani. Namun pemerintahan Usmani di Istanbul tidak menyetujui klaim Sayyid Fadl. Abdulhamid II menyatakan bahwa Usmani tidak melihat Dhofar memiliki posisi yang strategis untuk Usmani. ${ }^{16}$

Meskipun Seyyid Fadl tidak sukses dalam gerakan politik di Samudera Hindia, namun ia merupakan figur yang diakui dalam membangun koneksi tarekat Alawiyah. Banyak para Sayyid dari wilayah Samudera Hindia membangun kontak dengan Istanbul melalui koneksi Seyyid Fadl seperti Seyyid Abu Bakar bin Shihab (Singapura) dan Sayyid Ahmad bin Sumayt. ${ }^{17}$ Bahkan Ahmad bin Sumayt selama kunjungannya ke Istanbul melakukan 
kerja sama dengan Seyyid Fadl dalam menuulis biografi/manaqib dari ayah Sayyid Fadl. Hubungan antara Seyyid Fadl dan Ahmad bin Sumayt ini adalah antara guru dan murid dalam tarekat Alawiyah. Perlu diketahui juga bahwa Ahmad bin Sumayt juga memiliki jaringan kekerabatan yang buas di Jawa.

Seperti yang sudah disebutkan di atas bahwa banyak sekali keluarga Sayyid yang bermigrasi ke Indonesia. Migrasi Hadrami merupakan kegiatan aktivitas lelaki. Dalam hal ini para perempuan Hadrami menolak untuk melakukan migrasi, mereka memilih untuk tinggal di kampung halaman (Hadramaut). Untuk itu praktisi poligami merupakan hal yang wajar karena mereka melakukan migrasi seorang diri ke mahjar (tempat berdiaspora) dalam waktu yang tidak tentu sehingga mereka menikah lagi dengan perempuan di wilayah mahjar. ${ }^{18}$ Perkawinan dengan perempuanperempuan pribumi ini menjadikan posisi para Hadrami di Indonesia semakin kuat karena mereka mampu beradaptasi dengan lingkungan sekitar melalui jaringan keluarga pribumi dari pihak perempuan. Selain itu posisi mereka, para Sayyid, yang dianggap sebagai orang suci oleh para pribumi di Indonesia membuat mereka semakin mudah diterima oleh masyarakat.

Jejak keberadaan para Sayyid dari Tarekat Alawiyah ini dapat dilihat dari kuburan sucinya seperti yang ada di Surabaya. Makam di Surabaya ini adalah makam wali Muhammad bin Aydarus al-Habashi (meninggal tahun 1919) dan Muhammad bin Ahmad al-Mihdar (meninggal tahun 1926. Pengaruh Wali Hadrami yang kuat bahkan bertahan hingga sekarang. Keberadaan mereka, meskipun sudah meninggal, memberikan kesan suci dan sakral. Hal ini terlihat dari makam Muhammad bin Aydarus al-Habashi (meninggal tahun 1919) dan Muhammad bin Ahmad al-Mihdar (meninggal tahun 1926). Mereka dimakamkan bersama Pangeran Hasan bin Umar bin al-Habashi (meninggal 1854). Gambaran kuburan ini sebelum dimakamkannya dua wali dari tarekat Alawiyah adalah terkesan menyimbolkan kemewahan, namun setelah dimakamkannya dua wali dari tarekat Alawiyah mengubah identitas makam tersebut menjadi sangat sakral. Dengan kata lain, keberadaan makam wali di pemakaman Pangeran Hasan telah mengawali pembangunan liturgi yang menghasilkan perubahan atau transfigurasi ke menjadi situs yang bersifat saleh atau suci sehingga menghilangkan identitas sebelumnya. ${ }^{19}$ Dari sini kita dapat melihat bahwa keberadaan para wali dari tarekat Alawiyah Hadrami di Indonesia memberikan pengaruh yang sangat besar terhadap masyarakat. 
Untuk itu tidaklah mengherankan jika keberadaan makam Sayyid Husein bin Abu Bakar al-Aydarus di Batavia tidak hanya menjadi simbol Islamisasi, tetapi juga menjadi simbol dari jaringan spiritualitas yang mengikat wilayah-wilayah di Samudera Hindia pada masa modern. Dalam hal ini Usmani merupakan aktor yang menjaga jaringan spiritualitas di wilayah Samudera Hindia sehingga menghubungkan antara Istanbul dengan Batavia.

\section{PERBAIKAN MAKAM SAYYID HUSEIN BIN ABU BAKAR AL- AYDARUS OLEH USMANI}

Seyyid Husein bin Abu Bakar al-Aydarus adalah figur yang penting dalam komunitas Hadrami di Indonesia. Dia wafat pada tahun 1798 setelah mengabdikan dirinya untuk mengajarkan agama Islam. Setelah wafat, dia memperoleh reputasi sebagai orang suci sehingga makamnya menjadi makam keramat. Makamnya berada di Luar Batang, Batavia, yang makan di sana didirikan masjid juga sebagai pusat ziarah. Para peziarah yang mengunjungi makam Sayyid al-Aydarus tidak hanya orang pribumi tetapi juga orang Cina dan Indo. Mereka menganggap makam tersebut membawa keberuntungan sehingga banyak yang memohon permintaan seperti memohon kesuksesan bisnis, memperoleh keturunan, dan lainlain. Bahkan dilaporkan, hasil penjualan dari barang-barang keramat yang ada di sana mencapai 8.000 gulden setahun. ${ }^{20}$

Seperti yang disebutkan di atas, bahwa dalam masyarakat yang absen, maka diperlukan upaya untuk mengingat melalui catatan dalam bentuk silsilah. Selain itu upacara seperti berdoa merupakan bagian dalam kegiatan masyarakat yang diaspora. Melalui upacara seperti haul (peringatan kematian seseorang), maka ini merupakan bentuk perkumpulan Arab diaspora sehingga posisi makam keramat bagi Hadrami di Indonesia sangatlah penting sebagai pengingat mengenai silsilah mereka. Menurut Fajrie Alatas setelah periode Post-kolonial, haul, yang sebelumnya merupakan ajang berkumpul diaspora Arab bertransformasi menjadi media integrasi terhadap negara Indonesia yang sudah merdeka sehingga haul menjadi bagian dari komunitas Hadrami untuk mengidentifikasi keindonesiaan, sementara tetap memelihara genealogi atau silsilah tarekat Alawiyah. Dalam hal ini, haul mencoba membangun jaringan antara tokohtokoh tarekat Alawi dengan ulama lokal yang bergelar Kiai. ${ }^{21}$ Demikian keberadaan makam tokoh tarekat Alawiyah di Indonesia sangat penting 
bagi komunitas Hadrami.

Pada akhir abad ke-19, makam ini pun menjadi penghubung bagi komunitas Hadrami dengan Usmani yang berpusat di Istanbul. Setelah Abdulhamid II naik tahta sebagai sultan sekaligus khilafah, dia mencoba mengeluarkan kebijakan politik luar negeri yang berccorak persatuan Islam (ittihad-i Islam). Untuk itu ia mulai membina hubungan luar negeri dengan negara-negara Muslim seperti Indonesia yang saat itu berada di bawah kekuasaan pemerintah kolonial. Konsulat Usmani yang di buka di Batavia tahun 1883, menjadi fondasi bagi hubungan Usmani dan Indonesia hingga keruntuhan Usmani di tahun 1923. Dalam membuka konsulat, Usmani banyak berhutang dengan komunitas Hadrami sehingga orang-orang Arab Hadrami menjadi perwakilah resmi Usmani di Batavia. ${ }^{22}$

Dengan peran komunitas Arab Hadrami yang begitu besar untuk Usmani maka mereka mencoba meminta kepada Usmani agar memberikan donasi untuk memperbaiki makam seorang wali yang berada di Batavia, yaitu Seyyid Husein bin Abu Bakar al-Aydarus. Bersamaan dengan permintaan tersebut maka Arab Hadrami meminta donasi untuk memperbaiki masjid dan membangun sekolah. Masjid yang dimaksud tidaklah disebutkan secara pasti, namun kemungkinan besar adalah masjid yang menjadi pusat ziarah ke makam Sayyid alk-Aydarus. Konsul Usmani di Batavia menjadi penghubung antara Arab Hadrami di Batavia dengan pemerintahan Usmani yang berpusat di Istanbul. Dalam dokumennya, Konsul Usmani menyebutkan bahwa "Di Batavia terdapat masjid besar yang rusak".23

Sadrazam atau Perdana Menteri Usmani, kemudian menerima surat dari Batavia mengenai permintaan donasi. Dalam dokumen tersebut, Usmani mengakui bahwa "makam al-Aydarus yang rusak adalah makam orang suci yang menyebarkan agama Islam". ${ }^{24}$ Berdasarkan hal tersebut, kita melihat adanya jaringan spiritual dari komunitas Arab Hadrami dengan khilafah yang berkedudukan di Istanbul. Surat permintaan akan pembangunan makam, masjid dan sekolah pun dilakukan dalam konteks hubungan antara Muslim dan khilafah yang berkedudukan di Istanbul. Bahkan dalam arsip di sebutkan bahwa komunitas Arab Hadrami mencoba menjelaskan kepada khalifah Usmani mengenai penderitaan yang terjadi akibat kolonialisme Belanda, sehingga pembangunan sekolah, serta perbaikan masjid dan makam Sayyid al-Aydrarus memiliki makna spiritual dan politik. Arab Hadrami menceritakan bahwa permintaannya untuk 
melakukan pembangunan masjid tidak diabaikan oleh Belanda. Laporannya menyebutkan bahwa "Terdapat Masjid besar di Batavia yang rusak dan para muslim di sana sama sekali tidak mendapatkan dukungan atau sokongan..."25 Untuk itu maka orang-orang Arab Hadrami menginginkan adanya kebaikan dari khilafah yang berkedudukan di Istanbul untuk menutupi kekurangan sebesar 30 juta (satuan mata uang tak disebutkan). ${ }^{26}$

Adanya upaya untuk memperbaiki makam Sayyid al-Aydarus dan masjidnya, maka koran Belanda, Nieuw Roterdamsche memandang upaya ini dengan rasa curiga. Adanya kecurigaan ini kemudian diketahui oleh Usmani yang menerjemahkan berita tersebut ke dalam bahasa Turki. Dalam dokumen tersebut disebutkan bahwa koran Nieuw Roterdamsche memandang jikalau donasi yang dikumpulkan oleh Istanbul untuk pembangunan masjid, sekolah dan makam Sayyid al-Aydarus berpotensi untuk membangkitkan persatuan Islam. ${ }^{27}$ Atas dasar itu pemerintah Belanda menaruh kecurigaan terhadap konsulat Usmani yang ada di Batavia.

Adanya permintaan mengenai perbaikan makam Sayyid al-Aydarus merupakan suatu kesempatan bagi sultan Abdulhamid II untuk menunjukkan kehormatannya sebagai khilafah yang melayani Muslim di luar wilayah Usmani. Atas bantuan yang diberikannya maka muslim di Indonesa berterima kasih kepada Sultan Abdulhamid II. Dalam dokumennya, Konsul Usmani di Batavia memuji sultan Abdulhamid II telah membantu muslim di Timur Jauh dalam mengurangi kemiskinan. Bahkan Konsul meminta sultan Abdulhamid II untuk mengirimkan utusan yang dapat berbicara mengenai agama kepada Muslim yang ada di Indonesia. ${ }^{28}$

Berdasarkan hal tersebut makam Sayyid al-Aydarus di Batavia secara tidak langsung menjadi penghubung spiritual antara Usmani dan Indonesia, khususnya di Batavia. Perbaikan makamnya beserta masjid yang menaunginya menimbulkan kontroversi karena Belanda melihat ini sebagai upaya untuk menciptakan gerakan persatuan Islam yang dapat mengancam keberadaan pemerintah kolonial Belanda di Indonesia. Namun dalam hal ini, penulis menilai bahwa kecurigaan Belanda sangatlah tidak berdasar karena Usmani sama sekali tidak berniat untuk menimbulkan pengaruh anti-kolonialisme yang dapat mengancam keberadaan Belanda. Apa yang dilakukan Usmani dalam konteks ini adalah untuk menciptakan jaringan spiritualitas yang mengikat Usmani sebagai negara Islam dengan Muslim lainnya yang berada di luar wilayah Usmani. 
Seperti yang telah diketahui, bahwa sejak gerakan Tanzimat di pertengahan abad ke-19, Usmani telah dibawa ke dalam dunia Barat sehingga Usmani banyak menyerap nilai-nilai modernisasi Barat. Hal yang paling terlihat dalam perubahan itu adalah adanya kesetaraan antara Muslim dan Non-Muslim sebagai instrumen utama dalam modernisasi. Atas itu pembagian masyarakat berdasarkan agama seperti sebelumnya tidak ada lagi. Namun sejak Abdulhamid II naik tahta pada tahun 1876 sebagai khalifah Usmani, dia berusaha untuk menghidupkan kembali tradisi Usmani. ${ }^{29}$ Dalam hal ini penulis melihat bahwa upaya Usmani untuk memperbaiki makam Sayyid al-Aydarus di Batavia merupakan bagian usaha Usmani dalam membangkitkan tradisi yang kembali pada tradisi Islam.

Di dalam artikel ini, penulis melihat tradisi dalam konsep yang dikemukakan oleh S. H. Nasr. Tradisi dalam hal ini bukan seperti tradisi yang ada dalam konsep Katolik sebagai traditio, namun ditempatkan dalam konteks Islam yang berarti al-din. Sehingga tradisi diartikan sebagai transmisi pengetahuan, praktisi, teknik, hukum, bentuk dan elemen lainnya baik oral maupun tertulis. Di sini tradisi merupakan sebuah usaha untuk memperlihatkan kebenaran yang dibawa oleh agen atau aktor seperti Rasul dan nabi. Singkatnya, tradisi dalam tulisan ini diartikan sebagai prinsipprinsip yang mengikat manusia kepada surga, untuk itu agama merupakan bagian yang penting dalam menghubungkan manusia dengan surga. ${ }^{30}$ Di samping itu konsep tradisi yang dikemukakan oleh Nasr berkaitan erat dengan empat pilar Usmani pada masa Abdulhamid II yaitu Islam, keturunan Osman (pendiri Usmani), perlindungan terhadap Haramain, dan memilihara Istanbul sebagai ibukota Usmani. ${ }^{31}$

Atas hal ini Sultan Abdulhamid II memberikan donasi kepada Arab Hadrami untuk perbaikan makam Sayyid al-Aydarus di Batavia merupakan bagian dari upaya Usmani untuk membangkitkan tradisi Islam yang sudah menghilang sejak adanya upaya Baratisasi setelah periode Tanzimat di pertengahan abad ke-19. Dengan donasi untuk perbaikan makam, pemerintah Usmani mencoba mengikat Muslim dengan khilafah yang berkedudukan di Istanbul dengan kesucian nilai-nilai relijius. Dapat dikatakan ini adalah bagian dari penghormatan Usmani kepada ulama yang telah berjasa dalam menyebarkan agama Islam di Indonesia seperti Sayyid al-Aydarus yang dimakamkan di Batavia.

Di samping itu, pengaruh para penganut tarekat Alawiyah yang mendapatkan posisi di Istanbul juga memainkan peran penting di dalam 
hal ini. Dalam tarekat, hubungan antara sesama penganut ajaran sufi bermuara dalam satu guru yang sama. Dalam tarekat Alawiyah mereka bermuara pada Ahmad bin Isa, seperti yang telah disebutkan. Untuk itu para penganutnya memiliki keterikatan meskipun mereka dipisahkan oleh spasial. Istanbul dan Batavia berjarak sangat jauh, namun keterikatan antara penganut tarekat Alawiyah di Istanbul dan Batavia tetap terjalin. Dalam perbaikan makam Sayyid al-Aydarus, kemungkinan besar pengaruh Sayyid Fadl dan pengaruh tarekat Alawiyah lainnya sangat kuat untuk mempengaruhi Usmani. Di samping Usmani memiliki misi tersendiri dalam memperkuat tradisi untuk mengikat khilafah, muslim dan Tuhan dalam konteks keagamaan.

\section{KESIMPULAN}

Keterikatan antara masyarakat Asia, khususnya Muslim sangat berbeda dari masyarakat Eropa seperti di Mediterania. Mungkin Braudel sudah tepat melihat ikatan masyarakat di Mediterania dengan kekuatan struktural seperti geografi dan ekonomi, namun kekuatan struktur tidaklah cukup untuk melihat masyarakat Asia yang Muslim. Hal ini ditunjukkan dalam Artikel ini. Artikel ini menunjukkan bahwa relasi antara pusat (Eropa) dan periferi (Asia, Afrika) dalam konsep yang dikemukakan oleh Wallerstein kurang mampu melihat hubungan antar negara Asia dengan baik. Untuk itu penulis menekankan harus adanya jaringan spiritualitas yang dibangkitkan oleh tradisi untuk mengikat masyarakat Asia khususnya Muslim di Samudera Hindia.

Makam Seyyid Husein bin Abu Bakar al-Aydarus merupakan simbol dan tanda dalam melihat keterikatan antara masyarakat Muslim di Samudera Hindia. Ini juga pertanda bahwa keterikatan Muslim di Samudera Hindia tidaklah mudah didominasi oleh kekuatan struktural kolonialisme seperti eksploitasi ekonomi. Hubungan antara masyarakat Muslim tetap kuat melalui jaringan spiritualitas yang dibangkitkan kembali melalui tradisi yang dibangun oleh masyarakat seperti Arab Hadrami. Dalam hal ini masyarakat Arab Hadrami dan Usmani mencoba menghidupkan kembali jaringan spiritualitas Usmani di Samudera Hindia melalui perbaikan makam Seyyid Husein bin Abu Bakar al-Aydarus di Batavia. Donasi perbaikan makam ini memperlihatkan bahwa Usmani sedang membangkitkan tradisi Islam di tengah arus modernisasi yang penuh dengan desakralisasi kehidupan publik. Namun justru perbaikan makam wali Seyyid Husein bin 
Abu Bakar al-Aydarus memperlihatkan bahwa pada akhir abad ke-19, Istanbul dan Batavia justru sedang terhubung melalui jaringan spiritual Samudera Hindia yang di hubungkan oleh tarekat Alawiyah.

\section{CATATAN AKHIR}

1 Versi awal dari dari artikel ini adalah makalah yang dipresentasikan di Seminar Internasional Sejarah "Interpreting 70 yeaars of Indonesian Independence amidst Global Changes in Historical Perspective” pada 20-22 Agustus 2015 di Universitas Indonesia, Depok. Terima kasih juga kepada para sejarawan, panitia dan peserta konferensi yang memberikan masukan atas makalah ini.

2 Arsip Bapbakanlýk Osmanlý Arpivi akan disingkat dengan BOA. Lihat BOA, YA.HUS 386/40

3 Fernand Braudel. (1992). Civilization 8 Capitalism 15th-18th Century (Berkeley-Los Angeles: University of California Press), hlm 24

4 Immanuel Wallerstein. The Modern World-System I: Capitalist Agriculture and the Origins of the European World-Economy in the Sixteenth Century (London, Los Angeles, Berkeley: University of California Press, 2011), hlm 7

5 K.N. Chaudhuri. Asia Before Europe: Economy and Civilisation of the Indian Ocean from the Rise of Islam do 1750 (Cambridge: Cambridge University Press,1992), hlm 29

6 Sugata Bose. A Hundred Horizons: The Indian Ocean in the Age of Global Empire. Cambridge Massachussetts: Harvard University Press, 2006); Eric Tagliacozzo. The Longest Journey: Southeast Asians and the Pilgrimage do Mecca .New York: Oxford University Press,2013); Engseng Ho. The Graves of Tarim: Geneaology and Mobility Cross the Indian Ocean. (Berkeley, Los Angeles, London: University of California Press, 2006).

7 Azmi Özcan. Pan-Islamism: Indian Muslim, the Ottomans and Britain 1877. 1924.Leiden: Brill, 1997); Cezmi Eraslan. II.Abdülhamid ve Ýslam Birliði: Osmanlý Devleti'nin Ýslam Siyaseti 1856-1908.Ýstanbul: Ötüken Nepriyat, 1992); Gökhan Çetinsaya. "II. Abdülhamid Döneminin Ýlk Yýllarýndan Ýslam Birliiði Hareketi” (Master Tesis tidak diterbitkan tahun 1988) Universitas Ankara

8 Seyyed Hossein Nasr. Knowledge and the Sacred. (New York: State University of New York, 1989),hlm 8

9 L.W.C. van den Berg. Orang Arab di Nusantara. (Jakarta: Komunitas Bambu,2010)., hlm 158

10 Ho. The Graves of Tarim, hlm 4

11 Ibid, hlm 37

12 Anne K. Bang. Sufis and Scholars of the Sea: Family Networks in East Africa 18601925 (London: Routledge,2003), hlm 24-25

13 Çetinsaya "II. Abdülhamid Döneminin Ýlk Yýllarýndan Ýslam Birliiði Hareketi” hlm.6-7

14 Ulrike Freitag. Indian Ocean Migrants and State Formation in Hadhramaut: Re- 
forming the Homeland. (Leiden, Boston: Brilll, 22003), hlm 129

15 Ibid,hlm 79.

16 P.Tufan Buzpýnar. 'Abdülhamit II and Sayyid Fadl Pasha of Hadramawt: An Arab Dignitary's Ambitions 1876-1900', The Journal of Ottoman Studies,1993,hlm 238.

17 Freitag.Indian Ocean Migrants, hlm 211

18 Ismail Fajrie Alatas. "Gold and Silver, Branden Horses, and Well-Tilled Land: Gender and Harami Migration” dalam Indonesian Feminist Journal, vol 3, nomor 1,(2015),hlm 8

19 Ismail Fajrie Alatas. "The Pangeran and Saints: The Historical Inflection of a Mia 19th-century Hadrami Mausoleum in East Java, Indonesia”. Indonesia and the Malay World, (2016) hlm 2

20 Berg.Orang Arab di Nusantara,hlm.146

21 Ismail Fajrie Alatas. "Pilgrimage and Network Formation in Two Contemporary Ba 'Alawi Hawl in Central Java”, Journal of Islamic Studies, (2014), Hlm 300

22 Ýsmail Hakký Göksöy. Güneydoðu Asya'da Osmanlý-Türk Tesirleri (Isparta: Fakulte Kitabevi, 2004),hlm 95. Untuk melihat peran komunitas Arab Hadrami sebagai mediator Asia Tenggara dengan Usmani lihat, Ýsmail Hakký Kadý "The Ottomans and Southeast Asia Prior to the Hamidian Era: A Critique of Colonial Perceptions of Ottoman-Southeast Asian Interactions" in A.C.S Peacock \& Annabel Teh Gallop (ed).From Anatolia to Aceh: Ottomans, Turks and Southeast Asia (London: British Academy, 2015); Jeyamallar Kathirathamby Wells "Hadhrami Mediators of Ottoman Influences in Indonesia” in A.C.S Peacock \& Annabel Teh Gallop (ed).From Anatolia to Aceh: Ottomans, Turks and Southeast Asia (London: British Academy, 2015).

23 BOA, YA.HUS 386/40, shafer 1316 (Juni 1898)

24 BOA, YA.HUS 386/40, shafer 1316 (Juni 1898)

25 BOA, YA.HUS 386/40, shafer 1316 (Juni 1898)

26 "inpasýna karar verilmip ise de cam olunan ianenin ipbu tamirat ve inpaata gayr kafi bulunduðuna otuz milyona balið olan (yang berjumlah) ve ýmra ve ýfrad-ý bila istipna hilafet mukaddes islamiyeye merbut bulunan oradaki ahl- Ýslam hakkýnda dahi bir eper lütuf ve inayet hazret hilafetpenahi olmak" lihat: BOA, YA.HUS 386/40 tanggal, shafer 1316 (Juni 1898)

27 "Batavyada bir mescid perif ve bir mekteb inpasý içun pehir mezkur kadýsý tarafýndan cem edilen ianeye Dersaadetce iptirak edildiðinden bunun kýlýnmak müstemlekatýnde ittihad islam içun gayretten hali kalmadýðýný müsebbit bulunduðundan bahýsla bazý ifadatý pamil "Nieuw Roterdamsche" gazetesinin Dersaadetten olup nepr ettiði mektubun tercümesi gönderildiðini” lihat BOA, YA.HUS 400/124, cemazilahir 1317 (October 1899)

28 BOA, YA.HUS 386/40, shafer 1316 (Juni 1898)

29 M.Pükrü Hanioðlu. A Brief History of the Late Ottoman Empire (New Jersey: Princeton Univeersity Press, 2008), hlm. 126

30 Nasr.Knowledge and the Sacred,hlm 62-63 
31 Selim Deringil. 'Legitimacy Structures in the Ottoman State: The Reign of Abdulhamid II (1876-1909)' in International Journal of Middle East Studies, Vol 23, No.3, (1991), hlm 346.

\section{DAFTAR PUSTAKA}

\section{Sumber Sekunder}

Alatas, Ismail Fajrie. 2015 "Gold and Silver, Branden Horses, and Well-Tilled Land: Gender and Harami Migration” dalam Indonesian Feminist Journal, vol 3 , nomor 1 ,

Alatas, Ismail Fajrie. 2014. "Pilgrimage and Network Formation in Two Contemporary Ba 'Alawi Hawl in Central Java”, Journal of Islamic Studies.

Alatas, Ismail Fajrie. 2016. "The Pangeran and Saints: The Historical Inflection of a Mia 19th-century Hadrami Mausoleum in East Java, Indonesia” in Indonesia and the Malay World,

Bang, Anne K. 2003. Sufis and Scholars of the Sea: Family Networks in East Africa 1860-1925.London: Routledge.

Berg, L.W.C. van den. 2010. Orang Arab di Nusantara. Jakarta: Komunitas Bambu.

Bose, Sugata. 2006. A Hundred Horizons: The Indian Ocean in the Age of Global Empire. Cambridge Massachussetts: Harvard University Press,2006.

Braudel, Fernand. 1992. Civilization $\mathcal{E}$ Capitalism 15th-18th Century. Berkeley-Los Angeles: University of California Press.

Buzpýnar, P.Tufan. 1993. 'Abdülhamit II and Sayyid Fadl Pasha of Hadramawt: An Arab Dignitary's Ambitions 1876-1900', The Journal of Ottoman Studies.

Çetinsaya, Gökhan. 1988. 'II. Abdülhamid Döneminin Ýlk Yýllarýndan Ýslam Birliiði Hareketi'. (Master Tesis tidak diterbitkan) Universitas Ankara.

Chaudhuri, K.N. 1992. Asia Before Europe: Economy and Civilisation of the Indian Ocean from the Rise of Islam do 1750. Cambridge: Cambridge University Press.

Deringil, Selim. 1991. "Legitimacy Structures in the Ottoman State: The Reign of Abdulhamid II (1876-1909)", International Journal of Middle East Studies, Vol 23, No.3.

Eraslan, Cezmi. 1992. II.Abdülhamid ve Ýslam Birliði: Osmanlý Devleti'nin Ýslam Siyaseti 1856-1908. Ýstanbul: Ötüken Nepriyat.

Freitag, Ulrike. 2003. Indian Ocean Migrants and State Formation in Hadhramaut: Reforming the Homeland. Leiden, Boston: Brilll.

Göksöy, Ýsmail Hakký. 2004. Güneydoðu Asya'da Osmanlý-Türk Tesirleri. Isparta: Fakulte Kitabevi.

Hanioðlu, M. äurü. 2008. A Brief History of the Late Ottoman Empire. New Jersey: Princeton Univeersity Press.

Ho, Engseng. 2006. The Graves of Tarim: Geneaology and Mobility Cross the Indian Ocean. Berkeley, Los Angeles, London: University of California Press.

Kadý, Ýsmail Hakký. 2015. "The Ottomans and Southeast Asia Prior to the Hamidian Era: A Critique of Colonial Perceptions of Ottoman-Southeast Asian Interactions" in A.C.S Peacock \& Annabel Teh Gallop (ed).From Anatolia 
to Aceh: Ottomans, Turks and Southeast Asia London: British Academy.

Nasr, Seyyed Hossein. 1989. Knowledge and the Sacred. New York: State University of New York.

Özcan, Azmi. 1997. Pan-Islamism: Indian Muslim, the Ottomans and Britain 1877. 1924. Leiden: Brill.

Tagliacozzo, Eric. 2013. The Longest Journey: Southeast Asians and the Pilgrimage do Mecca . New York: Oxford University Press.

Wallerstein, Immanuel. 2011. The Modern World-System I: Capitalist Agriculture and the Origins of the European World-Economy in the Sixteenth Century. London, Los Angeles, Berkeley: University of California Press.

Wells, Jeyamallar Kathirathamby. 2015. "Hadhrami Mediators of Ottoman Influences in Indonesia” in A.C.S Peacock \& Annabel Teh Gallop (ed). From Anatolia to Aceh: Ottomans, Turks and Southeast Asia. London: British Academy, 2015.

\section{Lampiran Arsip}

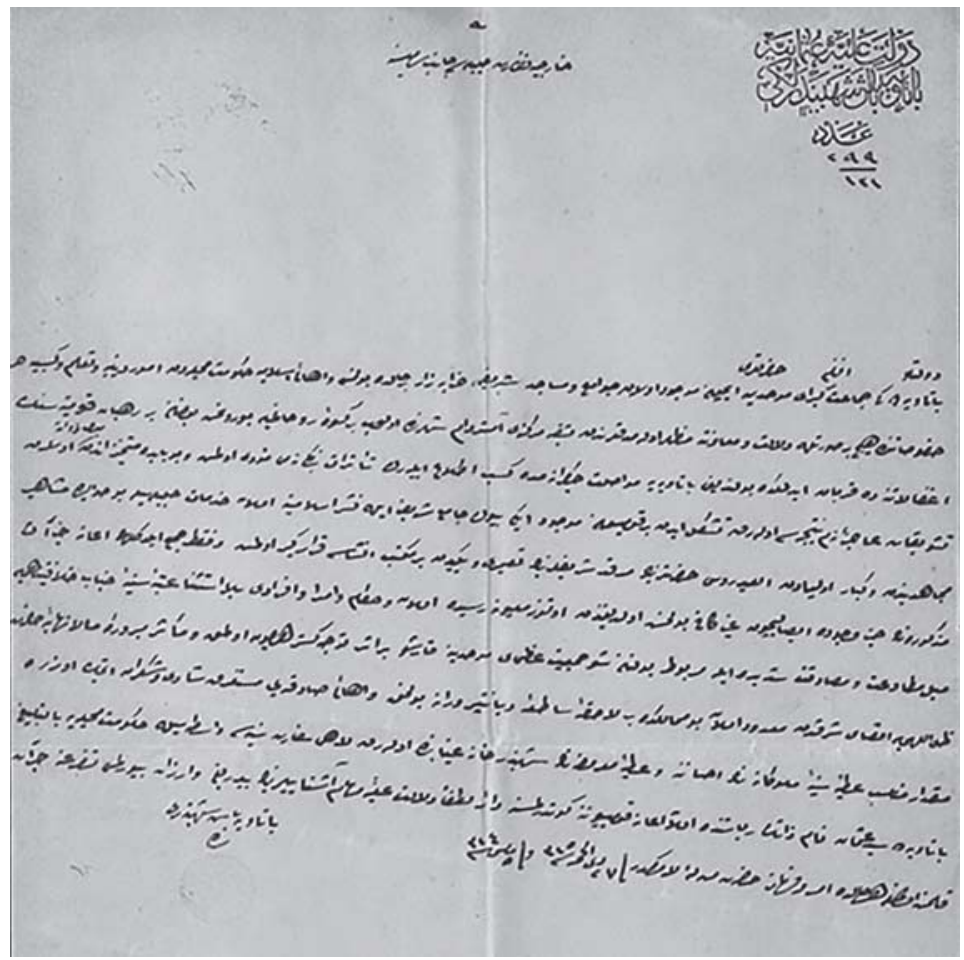

(BOA, YA.HUS.386/40) 


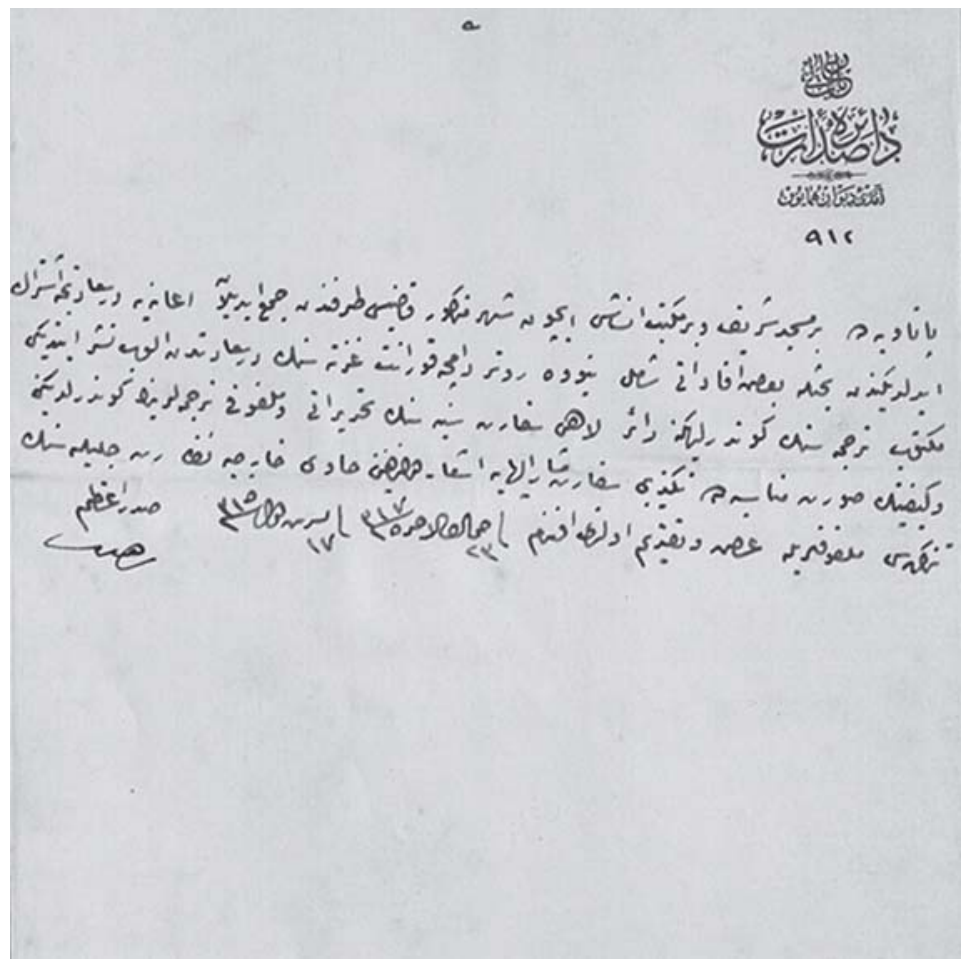

BOA, YA.HUS 400/124 